\title{
FOSTERING LANGUAGE AND THINKING SKILLS THROUGH ENGLISH AS A FOREIGN LANGUAGE CLASSROOM INTERACTION
}

\author{
Hoang Thi Hanh ${ }^{1 *}$, Nguyen Chi Duc ${ }^{2}$ \\ 1. Faculty of Linguistics and Cultures of English Speaking Countries \\ VNU University of Languages and International Studies, Pham Van Dong, Cau Giay, Hanoi, Vietnam \\ 2. Faculty of English Language Teacher Education \\ VNU University of Languages and International Studies, Pham Van Dong, Cau Giay, Hanoi, Vietnam
}

Received 18 September 2020

Revised 20 October 2020; Accepted 15 November 2020

\begin{abstract}
This study examined the effects of teacher talk on creating conditions for foreign language and thinking skills development. Through the lens of socio-cultural theory, we looked at the learning affordance/constraints that teachers in eight English speaking classes at a university in Vietnam created for learners via their actions and interactions with students. Two main, but contrastive interaction patterns emerged from this analysis. In one pattern, extended teacher talk could provide learners with more input, but at the same time deprive them of the opportunity to produce meaning-focused output and exercise highorder thinking skills. In the other, however, the interplay among teachers' proper use of referential questions, group work, extended wait-time, speakership assignment and appreciative responses was found to empower learners as active users of the target language as well as critical and creative thinkers. We therefore argue that by using talks that scaffold and facilitate learners' critical, divergent thinking, conceptualising process and effectively distributing classroom time for learners' thinking incubation and collaboration, teachers can create enabling conditions for learners to enhance both their L2 and thinking skills.
\end{abstract}

Keywords: teacher talk, classroom interaction, learning affordances, thinking skills, collaborative creativity.

\section{Introduction}

From the socio-cultural perspective (Vygosky, 1978, 1987), learning is socioculturally co-constructed via their interaction with teachers and peers. Accordingly, interaction in language classroom is a fertile learning environment in which learners practice their language use and enhance thinking skills (Donato, 2000; Sfard, 1998; Young \& Miller, 2004). In this environment, language is not merely a powerful mediator that facilitates learners' uptake of higher cognitive skills but also a product of this

\footnotetext{
1 Corresponding author. Tel: 0905598994.
}

Email: hanhhtulis@gmail.com. learning process. Empirical research has shown that teacher talk has a crucial role in creating either facilitative or impeding conditions for both cognitive development and language learning process (e.g., Li, 2011; see Hall \& Walsh, 2002; Thoms, 2012 for detailed accounts). In the majority of the studies that Hall and Walsh (2002) and Thoms (2012) have reviewed, they find that the teacher has the power to determine and channel the classroom discourse, enabling learners' interaction participation, optimizing their language use and creating many other learning affordances. They thus conclude that subtle changes in the way the teacher responds to learners' ideas can alter the course of interaction and create 
chances for further talk and hence potentials for advancing their language competence and cognitive skills (Thoms, 2012). However, what specific language use and interactional features of teacher talk construct such a favourable learning environment still remains underresearched in an English as a foreign language (EFL) context like Vietnam. In addition, most of the previous research in this area often centres around the effects on learning affordances of the Follow-up move in the typical Initiation-Response-Follow-up sequence of classroom interaction (henceforth referred to as IRF for short), but not that of the entire sequence. In addition, these studies tend to look at the opportunities that classroom interaction offers for learners' cognition growth in a relatively broad term. To be more precise, such a learning opportunity is not aligned with any well-established taxonomy of cognitive levels (e.g. Anderson et al., 2001, or Kolb, 1984). This study aims to fill these research gaps.

\section{Literature review}

\section{Socio-cultural lens to classroom interaction}

One core tenet in Vygotsky's sociocultural theory (1978) is the interdependence between language and cognition development, in which language is both a tool and a product of mental processing. From this, classroom interaction creates enabling conditions for learners' foreign language and thinking skills development (Donato, 2000; Hall, 1997; Sfard, 1998; Young \& Miller, 2004). However, according to Negueruela-Azarola, García and Buescher (2015), not all classroom interaction leads to development and learning. They specify that "some interaction leads to conceptual transformation through mindful engagement, some to learning of skills or noticing of forms, and some interaction is merely transactional and no new knowledge, ideas, or skills are gained from the exchange" (p. 234). Classroom interaction that leads to development involves learners in active engagement in understanding and appropriating new ideas, skills, and frames for thinking. Activities that create potential for development in a second language (L2) classroom, according to Negueruela-Azarola et al. (2015, p. 240) need to facilitate learners' "intentional memory, planning, voluntary attention and rational thinking." Such activities would involve learners in, for example, not only solving problems and finding quick answers but also in creating problems, planning, and formulating questions. As most of the previous research in this area finds socio-cultural theory a useful lens to examining learning affordances that classroom interaction can offer, we also apply this theoretical framework in the present study.

\section{Classroom interaction and foreign/second language learning}

Various studies with socio-cultural perspectives have been conducted in different contexts to investigate the effects that teacherstudent whole class interaction might have on L2 learning (e.g. Duff, 2000; Lin, 2000; Waring, 2008). Their findings have informed our instructional practice in various ways. Most of these studies look at the effects of the prominent Initiation-Response-Feedback (IRF) or Initiation-Response-Evaluation (IRE) pattern of interaction. Those studies consistently suggest that IRF/E and teachers' strict use of this interactional pattern might limit the learning opportunities for students because it can discourage students' idea contribution and language use (Lin, 1999a, 1999b, 2000; Nystrand, 1997). Interestingly, Waring (2008) finds that even explicit positive assessment (such as great, good, very good, excellent, perfect and the like) in the third part 
of IRE exchange that teachers usually assume to be positive and that it is sequentially and affectively preferred move, might actually hinder rather than promote learning because it effectively brings the sequence to a stop. Wells (1993), on the other hand, finds that the IRE interaction pattern is neither wholly good nor wholly bad in promoting learning. Its effects depend on whether or not language teachers expand the response phase to welcome more ideas from the target students or their peers before coming to the feedback/evaluation section (IR-delayed F/E). Along this line, other studies also find that subtle changes in teachers' follow-up move by acknowledging students' contribution, allowing it to expand or making it available for further class discussion and consideration can create significantly more learning opportunities for students (Boxer \& Cortes-Conde, 2000; Boyd \& Maloof, 2000; Consolo, 2000; Duff, 2000; Hall, 1997; Nassaji \& Wells, 2000; Sullivan, 2000).

\section{Classroom interaction and thinking skills}

Not just limiting the study to analysing the IRE or IRF pattern, Walsh (2002) examines the whole classroom discourse and argues that teacher talk can construct or obstruct learner participation in classroom communication, creating or limiting affordances for cognition growth. Constructive elements of teacher's actions might include direct error correction, content feedback, checking for confirmation, extended wait-time, scaffolding, while obstructive elements can be turn completion, teacher echo, teacher interruption (Walsh, 2002). In the same line, Li (2011) explores English language classroom in China and finds that by using referential questions, increasing wait time, reducing interruptions and adopting selective repair, the teacher can create, develop and manage space for students' thinking. Walsh $(2006,2011)$ and
Li (2011) call for further research to examine the cultural aspects of thinking skills and the micro-context in relation to thinking and language development in language education and teacher development.

Together, the review above suggests that classroom interaction has a strong impact on students' cognitive and communicative development. This study thus aims at investigating how such enabling interaction plays out in EFL classrooms in Vietnamese context and how teachers' talk can influence the cognitive and communicative learning conditions of the students. The findings hopefully can add foundation to language education and teacher professional development to help improve learning affordances for learners.

\section{Methodology}

\section{Research participants and context}

Participants were eight novice teachers who were teaching for other more experienced teachers to observe and mentor. All the teachers graduated from the same university and had not obtained Master degrees. They majored in English language teaching in their undergraduate degree.

Learners were all first year students majoring in English. Learners of different classes were supposed to be of the similar level of competence, because they had just passed the university entrance exam, and randomly assigned into different classes. These students had from three to seven or ten years of learning English in middle and high schools. They were at about pre-intermediate to intermediate level of English. Each class had roughly 25 students.

The textbook, New Inside-Out PreIntermediate (Kay \& Jones, 2008), was theme-based with themes such as animals, 
transport, places, education, and lifestyle. A course guide and supplementary materials were provided to support teachers and guide the activities in the class. However, teachers were allowed flexibility to design learning and teaching activities to facilitate learning.

\section{Data collection and analysis}

Data were collected from video recordings of eight English speaking classes, lasting around 50 minutes each. The teachers and students were aware of the video-taping process. The classes were observed by senior teachers who were both mentors and peers of the class teacher. The researchers were aware of the observer effects. It was taken into consideration that due to the observer effect, the teachers were probably doing their best to perform their teaching. However, this study did not aim to investigate, evaluate or generalise about the teachers' general practices, but just looked at how interactions played out and how certain actions of the teachers created learning affordance/constraint and influenced students' learning behaviours. Thus, it is expected that the observer effect would not majorly influence the interpretation of the results.

The data were transcribed in detail adequate to the analysis. All words were transcribed using conventional spelling, not spelling designed to indicate the actual pronunciation of the speakers. Since students were not native users of the language, and the analysis focuses on the effects of the teachers' talk on the learning opportunities created and how the learners took up the learning opportunities rather than the phonetic accuracy of the language use, the choice of conventional spelling was designed to make the transcripts easily readable. The time used for group work was measured and counted as wait-time.
The teachers were coded following letters of the alphabet as Teachers A, B, or C. Since this was whole class interaction, most of the students' names were not known to the researchers. Letter $\mathrm{S}$ was used to denote one student speaking in a turn; two Ss - SS - were used to denote several students or the whole class response. Whenever a student's real name was mentioned by a class member or by the teacher, the pseudonyms were used during the analysis and the report of the research.

All the transcribed interactional data were repeatedly read to find patterns. When a pattern was found, it was analysed qualitatively by seeing how the sequence unfolded. Through the lens of socio-cultural theory (Vygotsky, 1978, 1987), opportunities for students' language learning and thinking development were analysed in relation to features of the teachers' talks.

\section{Analysis and discussion}

Close repeated reading of the data reveals two major patterns of interaction. In one pattern, the teacher is the centre of the interaction process, guiding, asking questions, eliciting students' short answers, providing comments, correction, adding further information providing either language or background knowledge. In another pattern, teachers organise longer activities, giving students time for collaborative interaction and incubation of ideas before their long turn presentation of the group ideas. In three classes, only the first pattern of interaction is observed. In other five classes, the first pattern is found at the first half of the classes, and the second pattern is found in the second half. In this article, the two contrasting patterns of interaction from two critical cases, in which the actions of the teachers show clear evidence differing influences on students interaction pattern, were chosen for analysis. 
In this section, we present the two cases in which the roles of the teachers and students are differently constructed in the moment by moment of the interaction.

\section{Teacher as knowledge transmitter and students as knowledge recipients}

In this part of the lesson, the teacher is following a set of exercises in the textbook.
The topic of the lesson is about animals. Linguistically, the lesson focuses on vocabulary about animals and adjectives clauses describing features of animals. Before the following part of the interaction, the teacher asked students to make up sentences using the adjective clauses to describe features of animals. The following extract shows part of the whole class interaction with the teacher:

\section{Excerpt 1 with Teacher A}

\section{[....]}

$1 \mathrm{~S} 1$ : The person who... treat the animal is a vet

$2 \rightarrow$ T: The person...yes, hum.... is a.... a vet. Is vet is a full form of this word...

$3 \quad$ Anybody knows?

$4 \quad$ SS: vete veterinary

$5 \rightarrow$ T: Yes, veterinarian is the full form of the word, but because the word is TOO::

6 long, they tend to use the short form, is a vet ok like a doctor of animals...

$7 \quad$ NEXT the next sentence ... C ((pointing at a student))

$8 \quad[\ldots]$

9 S3: A tortoise is the animal that can live ... 70 years old

10 T: A tortoise //. And the last sentence Ngan

11 S3: An animal that..

12 T: The animal

13 S3: The animal that can recognize its image in the mirror is a dolphin

$14 \rightarrow$ T: A dolphin,

$15 \quad$ S3: A dolphin

$16 \rightarrow \quad$ T: Yes; in a mirror, image in a mirror, right, is a dolphin. Erh so what can we infer

17 about dolphin here. It can recognize its own image in a mirror so is it intelligent?

18 SS: Yes

19 T: Yes=. I can assure you that there are not many animals which can recognize

20 its own image in a mirror. If you have a cat you may have experienced the time 21 when they look at themselves in a mirror and try to FIGHT with the image (.) in 22 the mirror. Have you ever seen that?

23 SS: Yes

$25 \rightarrow \quad$ T: Ok. So the dolphin is a very intelligent animal in order to recognize its image 26 in a mirror. Ok. That's animal facts. You can find some other animal facts on page 27101 too. The same, nearly the same exercise on page 101. You have to match 28 some characteristics or some personalities of the oh sorry some properties of the $29 \rightarrow \quad$ animals with its name too using the same methods please tell me the answer for 30 exercise number 5 ok.. The first one has been done for you. The animal that can smell (...) is an elephant Ok. Thao the next sentence

((similar patterns are repeated throughout the 50 minute lesson)) 
The teacher calls on students one by one to make up sentences with adjective clauses and corrects their grammar and pronunciation mistakes. The pattern of interaction in this class includes: teacher's explicit instruction, teacher calling on one student, student making up one sentence using the set structure, teacher doing correction, teacher choosing one part of the sentence that may have something to extend on. Quantitatively, the turns taken by students are usually short; the longest one is just a sentence with guided content and structure, while the teacher has at least one extended turn in each episode.

This activity is language-focused learning. The teacher creates a condition for students to link a given meaning (i.e., a given prompt of idea) to a standard form (i.e., the prescriptive structure of relative clauses). Occasionally, the teacher initiates some unplanned Focus-onFormS (Loewen, 2018) episodes (e.g., lines 2 and 10) in order to introduce new lexical knowledge (e.g., line 2) or draw students' attention to their grammatical mistakes (e.g., line 10). In the former (i.e., line 2), students also have the opportunity to be exposed to an episode that the teacher talks about the language (e.g., the short form vs. the long form of a lexical item). This meta-linguistic talk opportunity is generally deemed to foster their language learning (Swain, 2005). However, the teacher's close-ended questions and rigid turn assignment restrict opportunities for students to produce meaning-focused output. They mechanically construct a sentence using a given prompt for ideas and a learnt sentence structure in a controlled practice. Even when they have already mastered such a sentence construction practice, they are still withheld there, instead of moving on to a more meaningful communicative practice. Other responses of these students are often in the form of an isolated word or phrase, but not a full sentence, let alone a group of sentences. Taken together, there is little evidence that the interaction pattern Teacher A designates fosters students' language development. This is a typical pattern of controlled practice.

For thinking development, the teacher creates few opportunities for their students to exercise their high-order thinking skills. In the extended turn, the teacher elaborates on the answers, adding further background knowledge (lines 5-7, 19-21). Factual knowledge can form a solid base for divergent thinking later, or a condition to foster students' creativity (Cropley, 1995). However, when this does not go with other conditions to push students' thinking to higher levels, we cannot conclude about the effectiveness of such knowledge foundation on students' thinking skill development. The requirement to form sentences with relative clauses using given cues is 'applying knowledge' (Anderson et al., 2001), but at a low level of application with the sentence structure and the content given in the textbook. Sometimes the teacher follows up the students' response by a question (e.g., lines 3 or 17) or recast (e.g., line 12). Unfortunately, most of such follow-ups merely require their students to recall factual information, centering around the lowest level of thinking in Bloom's revised taxonomy Remembering. There is no further observed evidence of students' practice applying the language creatively in more authentic, less structured, less controlled communication.

In fact, the teacher does attempt to climb up the ladder of thinking skills to such a high level as Analyzing (e.g., lines 20-21, 26). The teacher asks one higher order thinking question explicitly using the word "infer" (line 16), a higher level of understanding (Anderson et al., 2001). However, she immediately replaces the lucrative opportunities above with much 
impoverished ones that, again, merely require students to recall factual information. The inference she seems to expect from the students is just a judgment that "It can recognize its own image in a mirror, so is it intelligent?" and she says such comments herself rather than let it be produced by students. The teacher's turn is interspersed with students' minimal response "yes" (line 18), and then she continues comparing the dolphin's intelligence with that of a cat. Again, only minimal response from students is observed (line 23) to the teacher's question verifying a fact. She then explicitly names what she has provided as factual knowledge. Indeed, though the higher-order thinking word "infer" is explicitly used, there is no observable evidence of students' higher order thinking practice or development.

The teacher then coherently links to the next exercise requiring students to match factual information with the animals' names to produce sentence by sentence. It would not be problematic if this is just a first part of the lesson, where the teacher is organizing controlled practice to scaffold students' language use. However, the pattern is repeated throughout the whole session of 50 minutes with little students' language production or creative thinking observed. Possibly she is more concerned about completing the lesson, covering all the materials assigned, which may unintendedly hinder opportunities for fostering higher order thinking skills and communicative language practice.

The above patterns of interaction are similar to the most widespread form of interaction found in other studies, which is initiation - response - evaluation (IRE) or initiation - response - feedback (IRF). This pattern of interaction is consistently found to limit the chance of interaction of the learners (Hall \& Walsh, 2002; Li, 2011). Other studies indicate that just subtle changes in the $\mathrm{E}$ or $F$ of the IRE or IRF of the interaction can create chances for further contribution of the learners by elaborating on the ideas (Hall \& Walsh, 2002). The changes in $\mathrm{E}$ and $\mathrm{F}$ of the three part interactions can facilitate students to expand on their answers or qualify their initial responses (Nassaji \& Wells, 2000), affirm students' answers and make them available for others to consider (Boxer \& Cortes-Conde, 2000; Boyd \& Maloof, 2000). However, in the above excerpt, the extended turns of the teacher after each IRF/IRE are chances for the teacher to provide further information, to pass on her knowledge, possibly providing a base for students' creative thinking (Cropley, 1995), but does not facilitate students' active contributions. The students' responses to the extended sequences made by the teacher are only minimal one-word response said by the whole class.

Thus, in this episode, the teacher assumes the position of the transmitter of the knowledge using the target language extensively. The students are positioned as passive recipients of the knowledge, and we do not have evidence of the students' creative language use and cognitive development, even though the input provided could provide background for further language and thinking development.

\section{Teachers as facilitators and students as creative, collaborative and empowered users of the language}

In this lesson with a different teacher and a different class of the same level of proficiency, the topic is the means of transport. In the first part of the lesson, the teacher gives students in each group a set of pictures of different means of transport and asks them to match the picture with the vocabulary. The checking part 
is also typical IRE/IRF similar to the pattern of interaction found in the above class and in selected sections of other observed classes.
However, unlike the above teacher, after the $\mathrm{E} / \mathrm{F}$ moves, she does not move on to the similar accuracy checking exercises but organises a group activity as follows:

\section{Excerpt 2 with Teacher B}




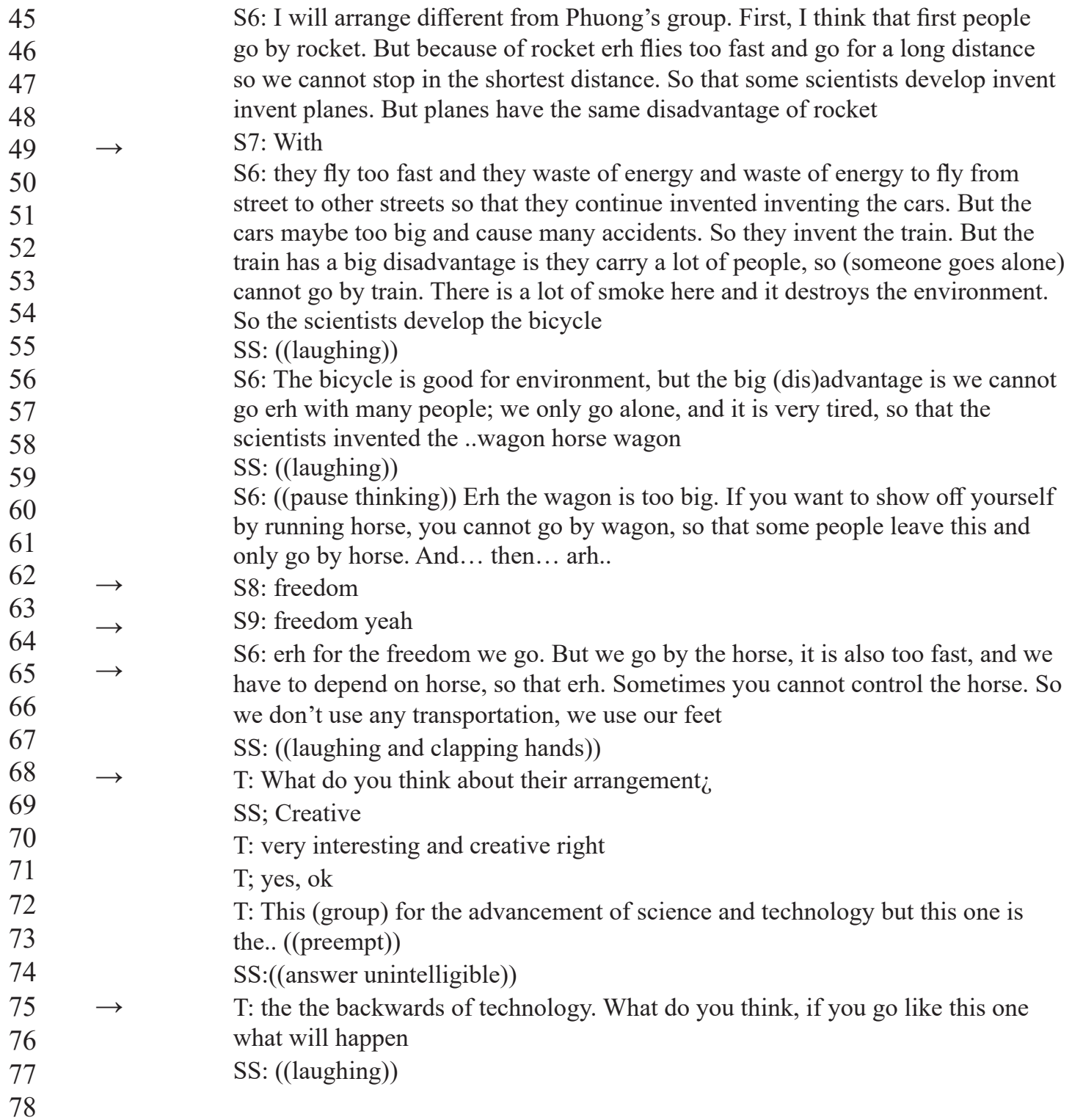

In this episode, the teacher asks students to work in groups and arrange the pictures of the means of transport in some kinds of order of their choice. She also suggests the time of appearance or any other types of arrangement. She allows students some time to discuss in groups. Then students are called on to the board to display their flow chart and explain the reasons behind their arrangement of the chart. When one group finishes, the teacher asks if any other groups have different ways of arrangement. Another group with the opposite way of arrangement compared to the first group presents their chart with explanation. The explanation is collaboratively contributed by other members of the class. We now first analyse the students' extended responses and then discuss how the teachers' moves facilitate such responses.

The "task" is a meaning-focused output activity where students make full use of their language resources to describe their sequence 
of the pictures. In this communicative activity, the students' language use is diverse and also includes several evidence of relative clauses. Such a pushed output task, according to Swain (2005), provides opportunities for students to notice gaps in their target language and directs their attention to relevant lexis or syntax in their upcoming exposure to language input. This often leads to moments of incidental Focus-on-Form (Loewen, 2018), and incidental learning. Such an opportunity has been offered and taken up several times (lines $34-35,49,63-65)$ in the episode. The teacher also employs a combination of visual aids, teamwork, preparation time and especially free turn-taking as a scaffolding to boost students' fluency in their speech delivery.

Cognitively, students are consistently required to exercise an orchestra of high-order thinking activities such as sequencing a list of transport modes (e.g., lines 1-2) (i.e., Analyze), explaining the logic behind such a sequence (lines 24, 26-27) (i.e., Evaluate) or improvising another sequence (line 41) (i.e., Create). The teacher requires students' higher order thinking when asking them to 'arrange' in a 'flow chart.' Arranging involves comparing and contrasting and organizing information - high level in the Bloom's taxonomy (Anderson et al., 2001). She adds suggestions of the criteria for arrangement as a form of scaffolding as "time of appearance," "kind of power," and encourages divergent thinking by adding "or any types," in "any kinds of charts." This instruction prompts her learners to approach the task from various perspectives and come up with different results. This lays the foundation for their contrast of the logics behind this picture arrangement. Additionally, wait-time is allowed for students to think and discuss with their peers. The detailed instructions requiring higher order thinking skills, the group work and the wait-time create enabling conditions for the students' extended and collaborative contributions that follow.

This interaction pattern also fosters their creativity. The teacher requires students to transfer information using multi-modal presentation of the same information such as the visual presentation of flowcharts (lines 1-6) and explaining their arrangement using verbal presentation (lines 13, 24, 26-27). Not stopping at the 'right' answer known and expected by the teacher, when student finishes one arrangement, she asks for alternatives and welcomes students' 'deviant' answers, promoting synthesizing/ creating skills (Anderson et al., 2001). Then, students arrange the picture in the reverse order. This idea is new to all students and even to our common perception, an example of mini-c creativity, "the novel and personally meaningful interpretation of experiences, actions and events" (Beghetto \& Kaufman, 2007, p. 73). Besides, the explanation demonstrates students' critical thinking when they bring in different issues like transport practicality, environment, and sense of freedom as the base for their picture arrangement.

The teacher also promotes higherorder thinking and creativity through the process of facilitating conceptualisation. The teacher asks further questions for students to select an appropriate concept that defines their sequence of pictures. After the first arrangement of the pictures, she asks: "what do they base on to arrange the pictures" (line 38) to prompt her learners to conceptualise their way of arrangement. This is successfully followed by students' response with a concept "the development of technology" (line 39). The teacher's prompt pushes students' thinking from description, arrangement of details to conceptualization, the act of moving up and down different levels of generality. After the students' second 
surprising and creative arrangement, the teacher asks "What do you think about their arrangement?" and scaffolding with "This (group) for the advancement of science and technology and this one is the..." to prompt conceptualization. This was followed by students' answers, but the answers are inaudible for transcription. She then takes up the students' answer by either paraphrasing or repeating "the backwards of technology". The teacher's expanding questions in the F moves stimulates her learners' logical explanation, conceptualization, comparison and contrast of different logical patterns.

Communicatively, students in this episode also show their co-construction of knowledge. For example, when the representative speaker of the first group cannot explain why human beings changed from using horses to using bicycles or trains, other members gave "brain" as a prompt, and she successfully picks it up and incorporates it in the next sentence "when our brain develop, we find different way, when we can..." (lines 34-35). Similarly, in explaining the second arrangement, when the second group speaker is talking about "riding horse" (line 62), she seems to get stuck through her long pause and hesitation. Then, another student just jumps in with 'freedom' as a hint (line 63). The student on the board quickly uptakes the suggestion and develops it into a whole reason why people choose to change from riding horse to walking (lines 65-67), which is followed by all students' laughter. These are examples of creative collaboration (Sawyer, 2008). One of the conditions that the teachers create to facilitate such co-construction knowledge above might lie in teachers' assignment of speakership. When the teacher expands the close-ended F move by adding further questions, she often assigns the speakership to one or several groups at a time rather than to a particular learner (lines 21, 26-27, 34-35, 38, 41, 69 and 76). This type of speakership assignment is found to allow learners to freely scaffold their group member who is currently taking the floor whenever needed. These can be clear examples illustrating Vygotsky's (1978) claim that most human learning starts from our interaction with others, and this speakership assignment obviously benefits learning in this regard.

It should be also noted that learners in this excerpt burst out laughing several times and even clapped hands as a compliment to their peers' responses. These laughters are, in turn, found to create a pleasant classroom atmosphere and thus engage learners in their learning processes. This goes in line with Liao et al. (2018)'s argument that playfulness is a form of creative pedagogy that both motivates students learning and sustains the learning process.

Seen together, the interaction pattern Teacher B designates indeed gives more affordances for both thinking and language learning than that by Teacher A. While teacher A provides input but gives little chance for students' practice, teacher B uses high-order thinking questions, wait-time, appreciative response to create enabling conditions for students' active collaborative participation and creativity. Students' planning, voluntary attention and rational thinking, according to Negueruela-Azarola et al. (2015), creates potential for development in a language classroom. The collaborative interaction pattern created can lead to conceptual transformation through mindful engagement of the students as the students here actively appropriate new ideas and frames for thinking. Students in class B take ownership of the floor and construct their own discourse. Linguistically, students use multiple sentence structures including simple, compound and complex sentences with various linking devices, forming the whole discourse of an argument. Despite some inaccuracy which does not hinder communication, the language 
use to explain complex ideas resembles real life discourse. While students in class A are constructed as recipients of knowledge, students in class B are active users of the language, independent, creative and critical thinkers, and creative and collaborative partners in communication and knowledge construction.

The findings in this study echo findings by Li (2011) and Walsh (2006) that certain teachers' move can obstruct or construct learners' thinking. In addition, it advances the literature by adding nuances to the picture. For example, the study describes specific types of instructions and of questioning techniques that can scaffold and facilitate critical, divergent thinking, conceptualizing process, effective use of class time for students' thinking and incubation, speakership assignment to facilitate ownership of floor and collaboration. The findings also confirm that language classroom is not only an environment for language development, but also for fostering higher order thinking.

\section{Conclusions and Implications}

Different classroom language uses can create different interaction patterns with differing learning potentials. Specifically, when a teacher only asks students to form sentences from given language and ideas, students' language practice is observed to be restricted. Even when the teacher explicitly uses higher order thinking verbs in the question, but without further enabling conditions such as wait time or group work and without expectation of a full creative answer from students, creative and critical thinking of students is not observed in the interaction. Extended teachers' talk can be a source of input for students, but without further activities created and when the concern about covering all the materials assigned gets in the way, little language and cognitive development from the students can be observed.
On the other hand, teachers' proper question types that require different levels and types of thinking, wait-time with group work, appropriate assignment of speakership and appreciative responses and questions that probe conceptualisation can give ownership of the interaction to the students and foster higher level thinking skills. This can empower them to actively use complex language and ideas to independently express and justify their own opinions, decide the purpose, structure, language patterns, and relationship with other interlocutors in their own L2 discourse. By using talks that scaffold and facilitate critical, divergent thinking, conceptualising process and effectively using class time for students' thinking incubation and collaboration, teachers can create enabling conditions for students' learning and thinking to develop.

Video-tapes of different types of classroom interactions can be used in English language teacher education courses to compare and contrast the effects of different ways of teachers' talk and designation of classroom interaction. This finding also provides strong empirical evidence to support the use of authentic classroom interaction analysis in research of useful English for specific purposes (ESP) in classrooms as suggested by Freeman et al. (2015). It also strongly supports the argument proposed by Walsh $(2002,2011)$ that working with classroom interaction data and analysing transcripts can significantly enhance teachers' understanding of their own practice and can help modify their classroom behaviours to enhance learning opportunities for students. This understanding of the microcontext in relation to thinking development can form the foundation for language education and teacher professional development ( $\mathrm{Li}$, 2011) so as to improve learning opportunities for learners. 
Cautions, however, should be taken into consideration in interpretation and application of this study. First, though students' levels are around pre-intermediate, they passed the entrance exam to a university majoring in English, their learning motivation might be higher than other groups of students. Thus, the findings might not be generalisable to other teaching contexts. Second, the study only concludes that such teachers' actions can create enabling conditions to foster students' language and thinking development, rather than causing such development.

\section{References}

Anderson, L. W., Krathwohl, D. R., Airasian, P. W., Cruikshank, K. A., Mayer, R. E., Pintrich, P. R., et al. (2001). A taxonomy for learning, teaching and assessing: A revision of Bloom's taxonomy of educational objectives. USA: Addison Wesley Longman, Inc.

Beghetto, R. A., \& Kaufman, J. C. (2007). Toward a broader conception of creativity: A case for mini-c creativity. Psychology of Aesthetics, Creativity, and the Arts, 1, 73-79.

Boxer, D., \& Cortés-Conde, F. (2000). Identity and ideology: Culture and pragmatics in content-based ESL. In J. K. Hall, \& L. S. Verplaetse (Eds.), Second and foreign language learning through classroom interaction (pp. 203-219). London: Routledge.

Boyd, M., \& Maloof, V. M. (2000). How teachers can build on student-proposed intertextual links to facilitate student talk in the ESL classroom. In J. K. Hall, \& L. S. Verplaetse (Eds.), Second and foreign language learning through classroom interaction (pp. 163-182). London: Routledge.

Consolo, D. A. (2000). Teachers' action and student oral participation in classroom interaction. In J. K. Hall \& L. S. Verplaetse (Eds.), Second and foreign language learning through classroom interaction (pp. 91-108). London: Routledge.

Cropley, A. J. (1995). Fostering creativity in the classroom: General principles. In M. A. Runco (Ed.), Creativity research handbook (pp. 83-114). Cresskill, NJ: Hampton Press.

Donato, R. (2000). Sociocultural contributions to understanding the foreign and second language classroom. In J. P. Lantolf (Ed.), Sociocultural theory and second language learning (pp. 27-50). Oxford: Oxford University Press.

Duff, P. (2000). Repetition in foreign language classroom. In J. K. Hall \& L. S. Verplaetse (Eds.),
Second and foreign language learning through classroom interaction (pp. 109-138). London: Routledge.

Freeman, D., Katz, A., Gomez, P. G. \& Burns, A. (2015). English-for-Teaching: Rethinking teacher proficiency in the classroom. ELT Journal, 69(2), 129-139. https://doi.org/10.1093/elt/ccu074

Hall, J. K. (1997). Differential teacher attention to student utterances: The construction of different opportunities for learning in the IRF. Linguistics and Education, 9(3), 287-311. https://doi.org/10.1016/ S0898-5898(97)90003-6

Hall, J. K. \& Walsh, M. (2002). Teacher-student interaction and language learning. Annual Review of Applied Linguistics, 22, 186-203.

Kay, S. \& Jones, V. (2008). New inside out: Preintermediate. Oxford: Macmillan Education.

Kolb, D. A. (1984). Experiential learning. Englewood Cliffs, NJ: Prentice Hall.

Li, L. (2011). Obstacles and opportunities for developing thinking through interaction in language classrooms. Thinking Skills and Creativity, 6(3), 146-158.

Liao, Y. H., Chen, Y. L., Chen, H. C., \& Chang, Y. L. (2018). Infusing creative pedagogy into an English as a foreign language classroom: Learning performance, creativity, and motivation. Thinking Skills and Creativity, 29, 213-223.

Lin, A. M. Y. (1999a). Doing-English-lessons in the reproduction or transformation of social worlds? TESOL Quarterly, 33(3), 393-412. http://doi. org/10.2307/3587671

Lin, A. M. Y. (1999b). Resistance and creativity in English reading lessons in Hong Kong. Language Culture and Curriculum, 12(3), 285-296. http://doi. org/10.1080/07908319908666585

Lin, A. M. Y. (2000). Lively children trapped in an island of disadvantage: Verbal play of Cantonese workingclass schoolboys in Hong Kong. International Journal of the Sociology of Language, 143(1), 6383. https://doi.org/10.1515/ijs1.2000.143.63

Loewen, S. (2018). Focus on form versus focus on forms. In J. I. Liontas et al. (Eds.), The TESOL encyclopedia of English language teaching (Vol. 5, pp. 2625-3000). Hoboken, NJ: John Wiley and Sons, Inc. https://doi.org/10.1002/9781118784235. eelt0062

Nassaji, H. \& Wells, G. (2000). What's the use of 'triadic dialogue'? An investigation of teacherstudent interaction. Applied Linguistics, 21, 376406. https://doi.org/10.1093/applin/21.3.376

Negueruela-Azarola, E., García, P. N., \& Buescher, K. (2015). From interaction to intra-action: The internalization of talk, gesture, and concepts in the Second Language classroom. In N. Markee (Ed.), The handbook of classroom discourse and interaction (pp. 233-249). Oxford: John Wiley \& Sons, Inc. 
Nystrand, M. (1997). Dialogic instruction: When recitation becomes conversation. In M. Nystrand, A. Gamoran, R. Kachur, \& C. Prendergast, (Eds.), Opening dialogue: Understanding the dynamics of language and learning in the English classroom (pp. 1-29). New York: Teachers College Press.

Sawyer, R. K. (2008). Group genius: The creative power of collaboration. New York: BasicBooks.

Sfard, A. (1998). On two metaphors for learning and the dangers of choosing just one. Educational Researcher, 27, 4-13. https://doi.org/10.2307/1176193

Sullivan, P. N. (2000). Playfulness as mediation in communicative language teaching in a Vietnamese classroom. In J. P. Lantolf (Ed.), Sociocultural theory and second language learning (pp. 115-132). Oxford: Oxford University Press.

Swain, M. (2005). The Output Hypothesis: Theory and research. In E. Hinkel (Ed.), The handbook of research in second language teaching and learning (pp. 471-483). London: Lawrence Erlbaum Associates, Publishers.

Thoms, J. J. (2012). Classroom discourse in foreign language classrooms: A review of the literature. Foreign Language Annals, 45, 8-27. https://doi. org/10.1111/j.1944-9720.2012.01177.x

Vygotsky, L. (1978). Mind in society. Cambridge, MA: Harvard University Press.

Vygotsky, L. (1987). Thinking and speech. In R. Rieber, \& A. Carton, A (Eds.), L. S. Vygotsky collected works (Vol. 1, pp. 39-285). New York: Plenum.

Walsh, S. (2002). Construction or obstruction: Teacher talk and learner involvement in the EFL classroom. Language Teaching Research, 6(1), 3-23. https:// doi.org/10.1191/13621688021r095oa

Walsh, S. (2006). Investigating classroom discourse. London: Routledge.
Walsh, S. (2011). Exploring classroom discourse: Language in action. London: Taylor and Francis.

Waring, H. Z. (2008). Using explicit positive assessment in the language classroom: IRF, feedback, and learning opportunities. The Modern Language Journal, 92(4), 577-594. https://doi.org/10.1111/ j.1540-4781.2008.00788.x

Wells, G. (1993). Reevaluating the IRF sequence: A proposal for the articulation of theories of activity and discourse for the analysis of teaching and learning in the classroom. Linguistics and Education, 5(1), 1-37. https://doi.org/10.1016/ S0898-5898(05)80001-4

Young, R. F. \& Miller, E. R. (2004). Learning as changing participation: Discourse roles in ESL writing conferences. Modern Language Journal, 88 , 519-535. https://doi.org/10.1111/j.0026-7902.2004. t01-16-.x

\section{APPENDIX}

\section{Transcription conventions}

(.) A tiny pause of less than a second.

(1) Numbers in parentheses indicate silence or wait-time rounded by seconds.

? A rising intonation.

$i \quad$ A rise to mid-high tone

OR Loud sounds.

(( )) Transcriber's descriptions.

$\rightarrow \quad$ Parts of an extract discussed in the text. 


\title{
PHÁT TRIỂN NGÔN NGŨ̉ VÀ TỦ DUY THÔNGQUATƯƠNGTÁC TRONG LỚPHỌCTIẾNGANH
}

\author{
Hoàng Thị Hạnh ${ }^{1}$, Nguyễn Chí Đức ${ }^{2}$
}

1. Khoa Ngôn ngũ và Văn hóa các nước nói tiếng Anh

Truờng Đại học Ngoại ngũu, Đại học Quốc gia Hà Nội

2. Khoa Su phạm tiếng Anh

Truờng Đại học Ngoại ngũu, Đại học Quốc gia Hà Nội

Phạm Văn Đồng, Cầu Giấy, Hà Nội, Việt Nam

Tóm tắt: Nghiên cứu này xem xét tác động của các chiến lược lời nói khác nhau của giáo viên đối với việc kiến tạo các điều kiện hướng đến sự phát triển ngôn ngữ và tư duy của người học trong lớp học tiếng Anh. Sử dụng lý thuyết văn hóa xã hội học, chúng tôi nghiên cứu cách thức tám giảng viên đại học tạo ra cơ hội cũng như cản trở việc phát triển năng lực tư duy và ngôn ngữ của người học thông qua các tương tác trong lớp học. Báo cáo này phân tích hai loại hình tương tác chính được tìm thấy. Trong loại hình thứ nhất, việc giáo viên đưa ra những lời giải thích dài và chi tiết có thể cung cấp thêm nguồn ngôn ngữ và kiến thức đầu vào cho người học, nhưng lại ảnh hưởng đến thời gian và cơ hội thực hành ngôn ngữ và sử dụng tư duy ở bậc cao hơn. Ở loại hình thứ hai, giáo viên phối kết hợp giữa việc sử dụng câu hỏi thực, tổ chức làm việc nhóm, kéo dài thời gian chờ đợi câu trả lời, để mở cho người học tham gia tương tác và hồi đáp gợi mở. Sự phối kết hợp này đã kiến tạo cơ hội cho người học chủ động sử dụng ngôn ngữ và phát triển tư duy sáng tạo và tư duy phản biện. Như vậy, bằng việc sử dụng ngôn từ có tính gợi mở và hỗ trợ tư duy, phân bổ thời gian cho người học suy nghĩ, ấp ủ các ý tưởng và trao đổi, phối hợp với nhau, giáo viên đã góp phần kiến tạo các điều kiện thuận lợi cho sự phát triển cả ngôn ngữ và tư duy của người học.

Tù khóa: chiến lược lời nói của giáo viên, tương tác trong lớp học, cơ hội học tập, kỹ năng tư duy, sáng tạo hợp tác. 